\title{
A Puma M-26-15-ös MRAP és szomáliai alkalmazásának háttere
}

2 011. október 16-án az Operation Linda Nchi (A nemzet megmentése) művelet keretében a Kenyai Védelmi Erők (Kenyan Defence Forces - KDF) fő erői átlépték a kenyai-szomáli határt, hogy csapást mérjenek a Szomália déli területein tevékenykedő, Nairobi számára is egyre nagyobb kihívást jelentő radikális iszlamista alShabaab csoportjaira. ${ }^{1}$ Bár ezt hivatalosan tagadták, a KDF valójában már hosszú idő óta készült a műveletre. Ezt támasztották alá nem csupán a szerzőnek a különféle kenyai szereplőkkel készített interjúi, ${ }^{2}$ hanem a kenyai haderő intenzív modernizációja is, amelynek keretében a Szomáliában várható aszimmetrikus hadviselés követelményeire igyekeztek felkészíteni csapataikat. Ennek egyik fontos elemét képezték a páncélozott járművek, amelyek elengedhetetlennek bizonyultak az al-Shabaab elleni harcokban. Az iszlamisták ugyanis már korábban is előszeretettel alkalmaztak improvizált robbanóeszközöket (IED) a velük szemben harcoló afrikai uniós békefenntartókkal szemben, súlyos élőerő-veszteségeket okozva ezzel. A helyzetet bonyolította, hogy a KDF rendelkezésére álló páncélozott szállító harcjárművek eleve kis védelmet nyújtottak az IEDkkal szemben, mert felépítésük (lapos test) és gyenge

\section{1. ábra. A Puma elődök egyike: a Casspir páncélvédett jármű}

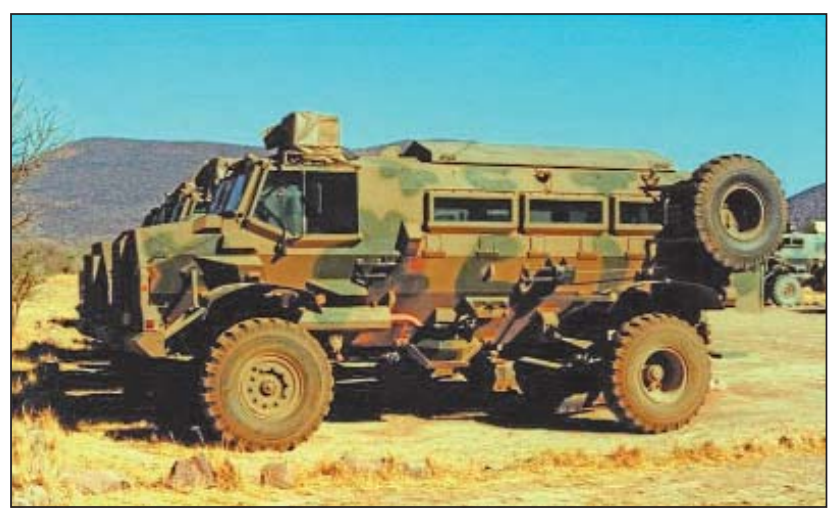

páncélzatuk kiszolgáltatottá tette őket az ilyen típusú támadásokkal szemben. Azok a járművek pedig, amelyek elegendő páncélvédettséggel rendelkeztek, nem voltak alkalmasak arra, hogy az infrastruktúrában rendkívül szegény dél-szomáliai területeken alkalmazzák őket, mivel a vízmosások, időszakos folyóvizek fölött átívelő hidak nem bírták volna el ezeket.

2011 októberében a KDF összesen 72 db AML-60/90-es Panhard, $12 \mathrm{db}$ Ferret, valamint $8 \mathrm{db}$ S52-es Shorland páncélozott harcjárművel rendelkezett, a gyalogság szállítására pedig $10 \mathrm{db}$ M-3-as Panhard és 52 db UR-416-os állt hadrendben. ${ }^{3}$ Ezt kiegészítette még bizonytalan számban néhány BTR-60-as, ${ }^{4}$ Saladin, ${ }^{5}$ Saracen, WZ551-es (Type 90/92), ${ }^{6}$ illetve 85-105 db közötti BRM. ${ }^{7}$ Az elmúlt években a modernizáció jegyében az Egyesült Államok nagyjából 100 Humwee-t adott több részletben szövetségesének. ${ }^{8}$ Mindezekre azonban igazak voltak a fentebbi észrevételek, amelyek korlátozták bevethetőségüket a műveletekben (nem beszélve arról, hogy számos öreg harcjármű valójában nem volt bevethető állapotban).

Így a KDF-nek égető szüksége volt arra, hogy beszerezzen egy olyan harcjárművet, amely alkalmas az első vonalbeli küzdelemre és a kenyai veszteségek mérséklésre. Ezen a területen az igazi áttörés akkor következett be, amikor Nairobi 20 millió USD értékben írt alá szerződést Dél-Afrikával Puma M-26-15-ös harcjárművek beszerzésére, amelyekből az első 67 db már a műveletek kezdetére megérkezett Kelet-Afrikába. ${ }^{9}$

\section{A Puma M-26-15 általános JellemzőI}

A Puma M-26-os gyártója a dél-afrikai OTT Technologies Ltd. Az 1980-as alapítású vállalat a dél-afrikai hadiipar egyik kulcsszereplője. ${ }^{10}$ A hidegháború és az apartheid vége új környezetet teremtett az ország hadiipara számára. Az új politikai vezetés - miután már nem kellett tartani a fekete lakosság általános felkelésétől - figyelme sokkal inkább a gazdasági és szociális biztonság felé terelődött, és

ÖSSZEFOGLALÁS: A Puma páncélozott szállító jármú a dél-afrikai hadiipar terméke. Megjelenésével az afrikai államok számára egy olyan MRAP beszerzésére nyílt lehetőség, amely alkalmas az első vonalbeli küzdelemre, könynyen kezelhető és karbantartható. Viszonylag kis tömege könnyebb szállíthatóságot és nagyobb mozgékonyságot jelent az afrikai kontinens gyenge infrastruktúrája mellett, valamint kielégítő védettséget nyújt a személyzetnek, ugyanakkor elérhetô áron szerezhetô be.

ABSTRACT: The Puma armoured personnel carrier is a product of the South African defence industry. With its appearance, an opportunity arose for the African countries to procure such a mine resistant ambush protected (MRAP) vehicle that is capable of fighting in the front line, easy to handle and maintain. Its relatively light weight provides the vehicle with easier transportability and higher manoeuvrability taking the weak infrastructure of the African continent into account; it protects the crew satisfactorily and it can be procured at a reasonable price as well.

KEY WORDS: South Africa, MRAP, Puma

\footnotetext{
* Oktató, Nemzeti Közszolgálati Egyetem - National University of Public Service, ORCID 0000-0002-1574-9343
} 


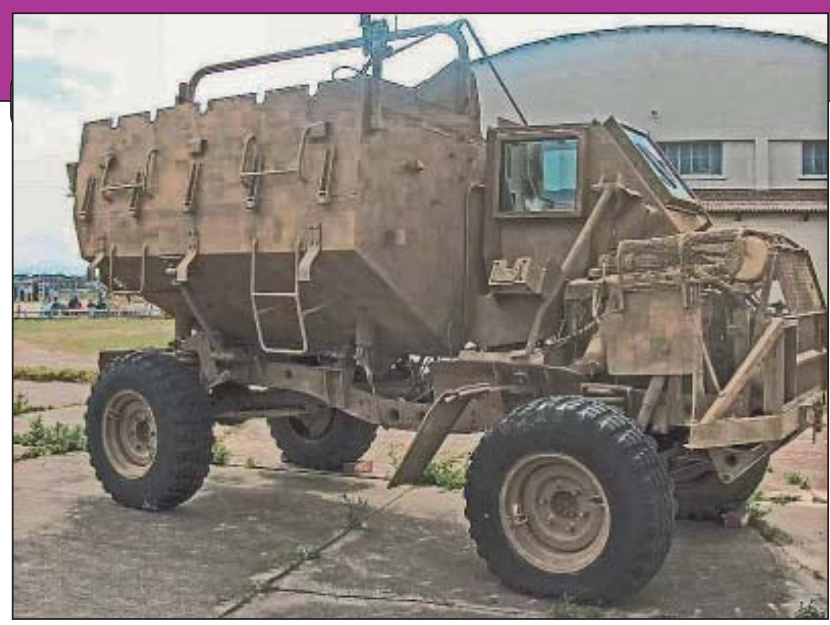

2. ábra. A világ első MRAP-je, a Buffel

a ,„kemény” katonai biztonság jelentősége háttérbe szorult. Ez súlyos érvágást jelentett a nagyrészt önellátásra termelő hadiipar számára is, amelynek számos ágazatát le kellett építeni. A kevés kivétel egyike volt a gyalogsági harcjárművek gyártása, amelyekre a Dél-afrikai Nemzeti Védelmi Erőknek (SANDF) továbbra is szükségük volt mind belbiztonsági, mind válságreagáló múveleteik során.

Dél-Afrikában az MRAP-k gyártása nem számított újdonságnak, sőt: az ország volt a fegyvertípus ,,bölcsője”, hisz az MRAP-k elődjének, az MRV-knek (mine resistance vechicle) a fejlesztése is itt vette kezdetét. A dél-afrikai hadsereg ugyanis magas veszteségeket szenvedett a rhodesiai határháborúkban, és szükségessé vált egy, a rhodesiai felkelők által elhelyezett aknák ellen védelmet nyújtó eszköz kifejlesztése. Ez lett a Buffel, majd annak továbbfejlesztett változata, a Casspir. A siker egyértelmü fokmérője volt, hogy míg korábban egy fölrobbant harckocsi-elhárító aknára átlagosan egy halott és két sebesült jutott, a Buffel esetében 21 detonációra csak egy elesett jutott, míg a Casspir esetében bekövetkezett összesen 54 robbantás egyike sem járt halálos áldozattal. ${ }^{11} \mathrm{Nem}$ véletlen, hogy az amerikai tengerészgyalogság is a dél-afrikai harcjárművekből kiindulva, dél-afrikai segítséggel (a Technical Solutions munkatársai bevonásával) tervezte meg saját MRAP-jét, a Magyar Honvédség által is alkalmazott Cougart.

Az OTT ezt a hagyományt folytatta tovább, és ötvözte az elmúlt évek hadszíntéri (Irak, Afganisztán) tapasztalataival. Ennek egyik eredménye lett a Puma M-26-os. A $4 \times 4$ kerék meghajtásos, V-testű harcjármű eredeti rendeltetése alapján akna- és IED elleni fokozott védettségű közepes gyalogsági szállítójármű (MRAP). A korábbi MRAP-khez képest fontos követelmény lett, hogy javítsanak az eszközök stabilitásán, a V-test miatti magas felépítmény ugyanis borulékonnyá tette a járműveket (mint ahogy azt az afganisztáni magyar kontingenst ért, két katona halálával járó szerencsétlenség is mutatta). ${ }^{12} \mathrm{~A}$ Casspirhoz és az azt követően kifejlesztett Mambához képest jelentősen növelték a harceszköz könnyű- és kézifegyverekkel szembeni védettségét. A másik cél ugyanakkor az előállítási költségek csökkentése volt: a Puma csak akkor számíthatott komoly piacra, ha az OTT képes volt az amerikai és brit konkurenciánál jóval olcsóbban előállítani az MRAP-ket. ${ }^{13}$ A kiváló ár-érték arányt jól jelzi, hogy a KDF vásárlása esetén a járművek darabára alig 300000 USD körül mozgott. ${ }^{14}$ A Pumát parancsnoki, egészségügyi mentő és járőr változatban is gyártják, illetve különféle támogató fegyverekkel is ellátható. ${ }^{15} \mathrm{Az}$ alapvariánssal tíz katona szállítható, beleértve a személyzetet. A jármű üres tömege 7200 kg, a személyzettel és a felszereléssel együtt $8130 \mathrm{~kg}$, ami lehetővé teszi, hogy a gyengébb hidak is elbírják. (Az egy harcosra jutó tömeg 93 kg. - Szerk.) A jármű hosszúsága 5810 mm, szélessége 2265 mm, magassága 2710 mm. Csúcs- sebessége $100 \mathrm{~km} / \mathrm{h}$, ajánlott utazási sebessége $80 \mathrm{~km} / \mathrm{h}$. Maximális hatótávolsága úton $800 \mathrm{~km}$. A páncélzata a harckocsi-elhárító aknák és IED-k mellett a gépkarabélytűz ellen is védelmet biztosít ${ }^{16}$. A test mellső és oldalsó páncélvédettség B6+ szintű (NATO-szabvány szerint STANAG-1-es) ${ }^{17}$, vagyis képes felfogni három 7,62 × 51 mm-es, illetve 5,56 × 45 mm-es gépkarabély-lőszert egy 120 mm-es egyenlő oldalú háromszögnyi területen. ${ }^{18}$ A tető védettsége B4-es szintű (vagyis csak pisztolylőszer ellen hatékony). Az IED-k esetében a páncéltest a futómü alatt bekövetkező robbanás esetén $14 \mathrm{~kg}-n y i$, a test alatt bekövetkezett robbanás esetén 7 kg-nyi TNT hatásfokával egyenértékű detonációt képes felfogni. ${ }^{19}$

Az M-26-os sikerén felbuzdulva az OTT elkészítette a Puma M-36-os elnevezésű változatát is. Ez már 12 fő szállítására alkalmas, megnövekedett páncélvédettsége miatt ugyanakkor a tömege eléri a 14 tonnát, ami rontja bevethetőségét a gyenge infrastruktúrájú területeken. ${ }^{20}$

A Puma küzdőteréből a lövedékálló ablakoknak köszönhetően kiváló kilátás nyílik a környezetre. A személyzet számára 12 lőnyílás áll rendelkezésre, valamint lehetőség van egy $360^{\circ}$-ban elforgatható kupola felszerelésére, amely általában egy könnyű géppuskát hordoz. Szintén megoldható egy 60 mm-es aknavető vagy egy $40 \mathrm{~mm}$-es gránátvető felszerelésére is. ${ }^{21}$

\section{A Puma M-26-0s alváltozatal}

A PUMA első példányai még csak $4 \times 2$-es kerékmeghajtással készültek. Erről a változatról szinte semmiféle elérhető információt nem lehet fellelni, azt leszámítva, hogy a jármüveket sikeresen alkalmazták Irakban. ${ }^{22}$ Mivel az Egyesült Államok hadereje nem volt kellően felkészülve a közel-keleti hadszíntérre jellemző aszimmetrikus hadviselésre, különösen pedig a korábban soha nem látott mennyiségű öngyilkos és IED-támadásra (például csak minden hetedik amerikai jármű volt páncélozott) ${ }^{23}$, minden szóba jöhető MRAP-t igyekeztek beszerezni, hogy csökkentsék csapataik veszteségét. A Puma első változata is valószínűleg így kerülhetett Irakba. A $4 \times 2$ kerékmeghajtás azonban nem bizonyult elégségesnek, ezért átálltak a 4 × 4-es megoldásra.

\section{JÁRÖRVÁLTOZAT}

Az alaptípushoz képest megerősített fegyverezet és csökkentett személyzet jellemzi. Általában ezt a változatot szerelik fel a $40 \mathrm{~mm}$-es gránátvetővel, vagy a $60 \mathrm{~mm}$-es akna-

\section{3. ábra. A PUMA M-26-os járörváltozata a két könnyügép-} puskával

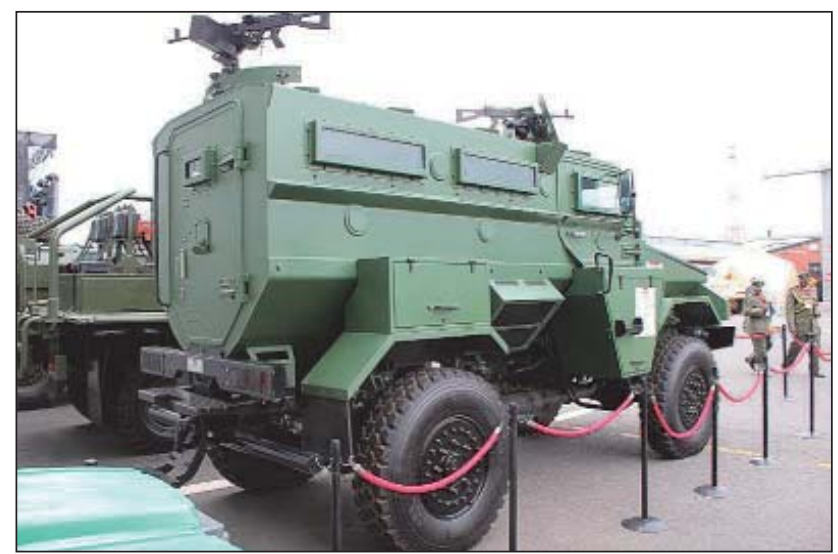




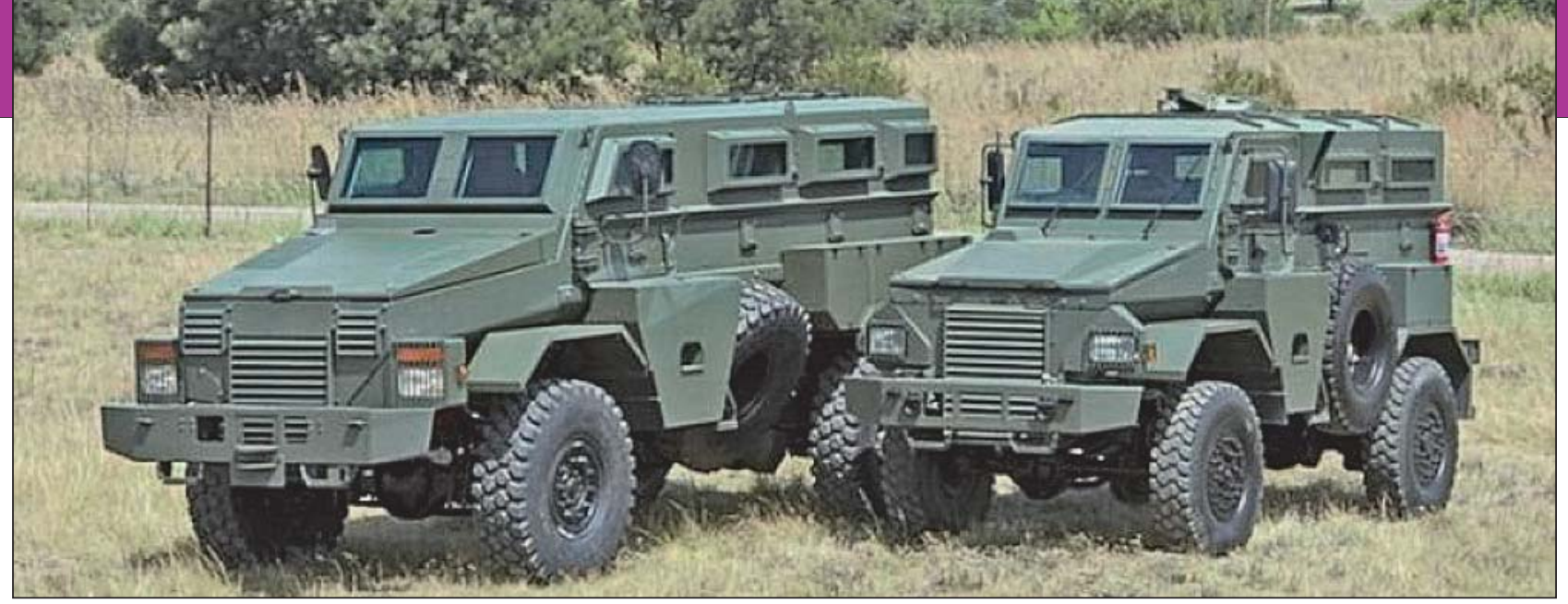

4. ábra. Egymás mellett a Puma M-26-16-os (jobbra) és nagyobb testvére, az M-36-os

vetővel. A tűzerőt a páncéltest két végében elhelyezett könnyügéppuskák növelik. A forgatható toronyban igény szerint felderítőeszközök és éjjellátó készülékek szerelhetők fel. A legénység száma 6 före csökken.

\section{EGÉSZSÉGÜGYI MENTŐ}

A változat személyzete a vezetőből és kétfős egészségügyi személyzetből áll. A többi változattól eltérően a jármű a Vörös Kereszt/Félhold felfestéssel készül a tetőn, a jármű oldalán és ajtajain. A belső tér viszonylag szük, csak négy ülő beteg vagy egy hordágy helyezhető el benne. A kiegészítők közé tartozik egy csappal ellátott, húsz literes víztartály, egy $60 \times 50 \times 30 \mathrm{~cm}$-es, fiókos láda az elsősegélyfelszerelés tárolására, egy ugyanakkora kosár az elsősegélycsomagok számára, egy hordágy a jármű külsejére felszerelve, illetve megfelelő belső világítás az ápolók számára a sebesültek ellátására.

\section{PARANCSNOKI VÁLTOZAT}

A változat személyzete szintén hat főből áll. A küzdőtérben helyet kap két darab $60 \times 50 \times 30 \mathrm{~cm}$-es láda, amelyeknek kihúzható fiókjaiban íróeszközök, térképtartók, tabletek kapnak helyet, egy $80 \times 100 \mathrm{~cm}$-es térképtartó tábla, két 24 voltos rádió, valamint megfelelő belső világítás. A parancsnoki jármű a test hátsó részénél nem rendelkezik oldalsó ablakokkal, a vezető ablakai, illetve a hátsó üveg elsötétíthető. ${ }^{24}$

\section{A PUMA M-36 Мк. 5}

$A z M-36-o s t$ lényegében új családnak is tekinthetjük. $A z$ M-26-os nagyobb ,,testvére" esetében a V-test minden irányban megnövekedett (magasság: $2767 \mathrm{~mm}$, szélesség: $2551 \mathrm{~mm}$, hosszúság: $6643 \mathrm{~mm}$ ), amiből a leglátványosabb a csaknem egyméteres hossznövekedés, ami lehetővé tette a szállítható személyzet számának két fővel történő emelését (összesen 12 főre). ${ }^{25}$ Miközben a jármű tömege a méretnövekedés és a pluszpáncélzat miatt csaknem 75\%-kal nőtt (8 t-ról 14 t-ra maximális terhelés mellett), a jármű sebessége és hatótávolsága nem változott, amihez jelentősen fokozni kellett a motor teljesítményét (145 LE-ről 220 LE-re) és az üzemanyag-tartály méretét (200-ról 290 literesre). ${ }^{26}$

\section{Az M-26-0s SzomÁLIÁBAN}

A KDF az M-26-osokat a dél-szomáliai hadszíntéren, a Beles Qooqani, Tabta, Afmadow, Jilib és Bardera körüli harcokban alkalmazta, amelyek stratégiai célja az alShabaab fő központjának, Kismayo kikötőjének az elfogla- lása volt. Az iszlamisták az esetek döntő többségében kitértek a szemtől szembeni konfrontáció elől, és rajtaütésekkel, IED-támadásokkal igyekeztek kivéreztetni és demoralizálni a kenyai alakulatokat. Az al-Shabaab akcióinak különösen a bázisok között mozgó járőrök, logisztikai szállítmányok voltak kitéve, éppen ezért alapvető fontosságú volt, hogy azok megfelelő védelem mellett mozoghassanak. Szemben az ugandai és burundi közvéleménnyel, a kenyai társadalom a médián keresztül viszonylag pontos információkkal rendelkezett a harcok menetéről. Ráadásul - szemben a két másik kelet-afrikai országgal - Kenyában valódi tétje van a parlamenti- és elnökválasztásoknak. Nairobi éppen ezért nem engedhette meg, hogy a másik két haderőhöz hasonló arányú veszteségeket szenvedjen el (Uganda és Burundi 2007 januárja és 2013 májusa között becslések szerint 3000 (!) halottat vesztett a szomáliai harcokban). ${ }^{27}$ Nem véletlen, hogy a frissen beszerzett Pumák azonnal bevetésre kerültek, és már 2011 végén feltűntek a hadműveletekről kiszivárgott fotókon. ${ }^{28}$

Az M-26-os előnyeit és teljesítményét jól mutatja egy, a nigériai Beeg Eagle biztonság- és védelempolitikával blogon megjelent 2012-es interjú Eeben Barlow-val, a híres dél-afrikai Executive Outcome katonai magánvállalat alapítójával. Az interjú készítője megkérdezte Barlowtól, hogy milyen járműveket javasolna a nigériai haderő számára a Boko Haram ellen viselt aszimmetrikus hadviseléshez. Az egykori kontraktor a Pumát nevezte meg legjobb választásként. Itt messze nem arról van szó, hogy Barlow saját országának szeretett volna piacot szerezni, hiszen a nigériai haderő korábban is rendelt például Casspirokat Pretoriától. A dél-afrikai szakember a következő érveket sorolta fel az M-26-os mellett, támaszkodva a folyamatban levő Operation Linda Nchi-re: a hadműveletek egy éve alatt számos támadás érte a PUMÁ-kat aknák, IED-k és EFP-k (Explosively Formed Penetretors - házilag készített ütőtányéros oldal elleni improvizált robbanószerkezet) ${ }^{29}$ részéről, a KDF mégsem szenvedett ezek során élőerő-veszteséget. Bár különböző becslések láttak napvilágot a KDF

5. ábra. M-26-os MRAP-k kísérik a páncélozatlan kenyai teherautókat Afmadow környékén

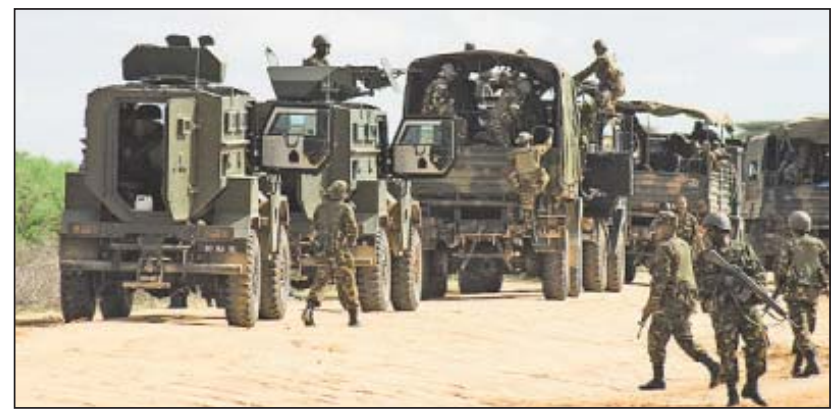


veszteségeiről (20-100 halott), ${ }^{30}$ azok messze elmaradtak az ugandai és burundi áldozatok számától.

A hadműveletek során fontos szempont volt a Puma egyszerű kezelése és javíthatósága. Az OTT az M-26-ost az afrikai kontinens csatatereire tervezte, ahol a jármű rossz infrastruktúrára, illetve korlátozott logisztikai és szerviz-támogatásra számíthat. Ahogy Barlow fogalmazott, ,,a jármű műszakilag olyan egyszerű megoldásokat alkalmaz, hogy gyakorlatilag bárki képes megjavítani és karbantartani, ami nagyban csökkenti a technikai támogatás szükségességét." ${ }^{11}$

Mindehhez járul még a kontraktor által is hangsúlyozott kedvező ár. A 300000 USD-be kerülő Puma fele-kétharmad annyiba kerül, mint egy Cougar. ${ }^{32}$ Ugyan a páncélvédettsége nem éri el előbbi szintjét, az esetek többségében elegendőnek bizonyul a harmadik világ csataterein. A Puma ezzel lényegében a ,szegény ember MRAP-jének” szerepét tölti be. Nem véletlen, hogy Nairobi - értékelve az alacsony árat és a minimalizált veszteségeket - további beszerzésekkel 150 darabra emelte a hadrendben tartott M-26-osok számát, ${ }^{33}$ és azok Kismayo 2012-es szeptemberi eleste után is az országban maradtak.

\section{ÖssZEGZÉs}

Az M-26-15-ös Puma tovább folytatta a dél-afrikai harcjármú-gyártás legnemesebb hagyományait. A Puma megjelenésével az afrikai államok számára egy olyan MRAP beszerzésére nyílt lehetőség, amely könnyen kezelhető és karbantartható, kielégítő védettséget nyújt a személyzetnek, ugyanakkor elérhető áron kapható. Bár páncélvédettség terén nem versenyezhet a nehezebb eszközökkel, mint a Cougar, kérdéses, hogy utóbbi kétszeres ára arányban áll-e az általa nyújtott előnyökkel.

A Puma viszonylag kis tömege könnyebb szállíthatóságot és nagyobb mozgékonyságot jelent az afrikai kontinens gyenge infrastruktúrája mellett (ahol a kritikus felső határt 10 tonna környékén szokták megadni). Ezek az előnyök azok, amelyek miatt a KDF a jármü beszerzése mellett döntött, és a Pumák a dél-szomáliai harcok során bizonyították kiválóságukat, amit Nairobi újabb vásárlásokkal méltányolt. Így megvan rá a lehetőség, hogy az OTT hamarosan újabb megrendeléseket szerezzen a jármű exportjára.

\section{JEGYZETEK}

1 A műveletről részletesen lásd: Marsai Viktor: $A$ kenyai védelmi erők 2011-12-es szomáliai harcai. In: Felderítő Szemle 11. évfolyam (2013), 3-4. szám, 65-99. o.

2 A 2012. január-február során készített, anonim interjúk a szerzó birtokában.

3 Military Balance 2011. The annual assessment of global military capabilities and defence economics. Routledge-IISS, London, 2011. 428-429.

4 BTR-60. http://weaponsystems.net/weapon.php?weapon=CC03\%20 -\%20BTR-60. Megtekintve: 2012. december 17.

5 Saladin. http://www.army-guide.com/eng/product586.html. Megtekintve: 2012. december 17.

6 WZ 551 (Type-90/92). http://www.army-technology.com/projects/ wz-551-type-9092-wheeled-armoured-personnel-carriers/. Megtekintve: 2012. december 17.

7 Kenya Should Act on Miningo Conflict. http://kenyastockholm. com/2009/04/14/kenya-should-act-on-migingo-conflict/. Megtekintve: 2012. december 17.

8 Kenya gets 41 Humwees to fight terrorism. http://www.canada.com/ edmontonjournal/news/story.html?id=9b00b0ce-4f89-49e5-9bfoc0eec1459c9e. Megtekintve: 2012. december 17.

9 Kenyan army took delivery 67 of South African-made PUMA M-26. http://www.armyrecognition.com/september_2012_new_army military_defence_industry/kenyan_army_took_delivery_of_67_south african-made_puma-_m-26_armoured_personnel_carrier_1109122. html. Megtekintve: 2012. december 17.

10 OTT - About us. http://www.ott.co.za/about-us/. Megtekintve: 2014 április 28.

11 Robert W. Russell: Does the mrap meet the US army's needs as the primary method of protecting troops from the ied threat? 2009. http://www.dtic.mil/dtic/tr/fulltext/u2/a502075.pdf. 49-50. Megtekintve: 2014. április 28.

12 Balesetben meghalt két magyar katona Afganisztánban. http://www. origo.hu/nagyvilag/20110517-meghalt-ket-magyar-katonaafganisztanban.html. Megtekintve: 2014. április 28.

13 PUMA M-26 4x4. http://osprea.com/setup/pdf/Puma\%20p4.pdf. Megtekintve: 2014. április 28.

14 Kenyan army took delivery 67 of South African-made PUMA M-26.

15 PUMA M-26 Mine and Blast Protected Vehicle. http://www.ott.co.za/ armoured-vehicles/puma-m26-mine-and-blast-protected-vehicle/. Megtekintve: 2014. április 28.

16 PUMA M-26-16. http://www.ott.co.za/wp-content/uploads/2012/06/ Puma-M26-15-MRAP-Eng1.pdf. Megtekintve: 2014. április 28.

17 ADD Cape Town South Africa 2010. http://www.armyrecognition. com/defense_army_military_world_worldwide_news_2010/show_ news_daily_online_aad_2010_pictures_video_actualit_s_photos africa_aerospace_defence_exhibition.html. Megtekintve: 2014. április 30.

18 European Ballistic Standards. http://www.interarmored.com/en/ ballistics/international-standards. Megtekintve: 2014. április 30.; PUMA M-26 4x4.

19 Uo.

20 Puma M36 Mk5 MRAP. http://www.ott.co.za/wp-content/ uploads/2012/06/Puma-M36-Mk5-MRAP-Eng1.pdf. Megtekintve: 2014. április 28.

21 PUMA M-26 4x4.

22 UPDATE ON THE PUMA M26-15. http:// eebenbarlowsmilitaryandsecurityblog.blogspot.hu/2009/09/ update-on-puma-m26-15.html. Megtekintve: 2014. április 30.; PUMA $\mathrm{M}-264 \mathrm{x} 4$

23 Elhangzik a No End in Sight dokumentumfilmben. Rendező: Charles Ferguson, 2007. http://www.noendinsightmovie.com/. Megtekintve: 2014.04.30.

24 PUMA M-26 4x4.

25 PUMA M36 Mk5 MRAP. http://www.militarysystems-tech.com/files/ militarysystems/supplier docs/Puma\%20M36\%20Mk5\%20MRAP. pdf. Megtekintve: 2014. április 30

$26 \mathrm{Uo}$

27 3,000 soldiers died in Somalia - UN. http://www.observer.ug/index. php?option=com_content\&view=article\&id=25250:3000-soldiershave-died-in-somalia-un. Megtekintve: 2014. április 30.

28 Kenya Army OTT PUMA M26 MRAP. https://beegeagle.wordpress. com/2011/12/31/kenya-army-ott-puma-m26-mrap/. Megtekintve: 2014. április 30

29 EOD, IED, UXO. http://bombariado.info.hu/tudastar/eod-ied/. Megtekintve: 2014. április 30.

30 Kenya Operation Linda Nchi. http://africadefensejournal.wordpress. com/2012/01/30/kenya-operation-linda-nchi-15-soldiers-killed-in100-days/. Megtekintve: 2014. április 30.

31 World Exclusive: Eeden Barlow. http://beegeagle.wordpress. com/2012/09/08/world-exclusive-eeben-barlow-africancounterinsurgency-and-expeditionary-operations-legend-speaks-tobeegeagles-blog-reviews-the-ott-puma-m26-15-mine-protectedvehicle-sheds-light-on-his-engage/. Megtekintve: 2014. április 30.

32 Cougar Minde Protected Armored Patrol Vehicle. http:// defense-update.com/products/c/cougar.htm. Megtekintve: 2014. április 30 .

33 Kenya Defence Forces. http://www.defenceweb.co.za/index. php?option=com_content\&view=article\&id $=31108$ :kenya-defenceforces\&catid=119:african-militaries. Megtekintve: 2014 . április 30. 